\title{
Squamous Cell Carcinoma as the Most Common Lesion of the Tongue in Iranians: a 22-Year Retrospective Study
}

\author{
Nafiseh Shamloo', Ali Lotfi ${ }^{1}$, Hamid Reza Motazadian², Hamed Mortazavi**, \\ Maryam Baharvand ${ }^{3}$
}

\begin{abstract}
The tongue has been globally considered as an indicator of general health for millennia. This study aimed to determine the prevalence and distribution of tongue lesions in an Iranian population. In this retrospective study, data from 6,435 oral biopsy reports over a 22-year period (1992-2014) were retrieved from archives of Oral and Maxillofacial Pathology Department, Shahid Beheshti Dental School, Tehran, Iran. These reports were analyzed according to age, sex, type of lesion and location. Prevalence of tongue lesions were reported as percentages. Out of total oral lesions, 238 (3.7\%) were found in the tongue, with the incidence peak $(42 \%)$ being between 41-60 years. Men constituted $53 \%$ and women $47 \%$ of patients. The youngest patient was a 3-year-old girl with pyogenic granuloma and the oldest one was a 93-year-old man with squamous cell carcinoma (SCC). SCC was the most common $(25 \%)$ lesion generally found in the lateral border of the tongue with a male predilection. The second and third most prevalent lesions of the tongue were benign keratosis (frictional keratosis) (13.4\%) and leukoplakia $(\mathbf{1 3 \%})$. White-red lesions $(\mathbf{3 8 . 6 \%})$ were the most frequent subgroup followed by neoplastic lesions $\mathbf{2 8 \%}$ ). Moreover, irritation fibroma, non-specific ulcers, squamous papilloma, and hemangioma were found as the most frequent lesions in their related subgroups.Given the high rate of SCC of the tongue in Iranian patients, this area should be examined more carefully by dental practitioners and physicians.
\end{abstract}

Keywords: Squamous cell neoplasms - tongue - mouth - Iran

Asian Pac J Cancer Prev, 17 (3), 1415-1419

\section{Introduction}

The tongue has been considered for millennia as an indicator of general health in both Western and Eastern medical philosophies (Koay et al., 2011). It is a muscular organ with specialized epithelium on the dorsal surface and a non- keratinized lining on its ventral aspect supported by a richly vascularized lamina propria containing nerves, fat cells, minor salivary glands, and lymphoid structures scattered throughout the body. Each of these elements can be the origin of a benign or malignant lesion. Tongue has different functions such as swallowing, tasting, suckling, general sensations and a key role in development of the jaws (Patil et al., 2013; Alaeddini et al., 2014).

Although easily examined, lesions of the tongue can present a diagnostic and therapeutic dilemma for clinicians (Alaeddini et al., 2014), hence recognition of tongue lesions is important to obviate from unnecessary or over treatment (Byahatti and Ingafou, 2010). Most of epidemiological reports on the prevalence of tongue lesions have been conducted in USA, Hungary, Jordan, Thailand and Turkey (Koayet al., 2011), which provide local clinicians with valuable information, elucidate variations between different regions, and help causative factors be detected. Continuous modifications in population life style and growing public tendency to keep optimum oral health result in possible changes in disease pattern, hence conducting studies on prevalence of oral lesions in different geographical regions seems imperative (Sabaet al., 2011; Mansour al., 2013; Alaeddini et al., 2014; Lotfiet al., 2015; Ramdasset al., 2015).

Iran, located in the West Asia archipelago, is the second largest and populous country in the Middle East with a population of approximately 75 million. Tehran-the capital of Iran- is one of the largest three cities in the Middle East (along with Istanbul and Cairo). Few epidemiologic reports regarding tongue lesions have been conducted in Iran (Alaeddini et al., 2014; Ramdasset al., 2015). Therefore in the present study we aimed to determine the prevalence and distribution of tongue lesions in an 
Iranian population during the recent 22-year period of 1992 to 2014 .

\section{Materials and Methods}

In this retrospective study, 6435 oral biopsy reports over a 22-year period (1992-2014) were retrieved from archive of Oral and Maxillofacial Pathology Department (the 2nd most authenticated oral pathology center in Tehran), Shahid Beheshti Dental School, Iran, and analyzed according to age, sex, type of lesion and location. Discounting normal variations such as fissured tongue, coated tongue, lingual varices, and racial pigmentation, tongue lesions were separated and fallen into six categories ofreactive/inflammatory hyperplasias, neoplasms, ulcerations, white-red lesions, hamartomas, and virusinduced lesions.

The specific location of the tongue lesions was recorded as tip, dorsal, lateral, ventral and base of the tongue. Descriptive statistics was used to measure the prevalence of tongue lesions in terms of sex,type of lesion and location by means of SPSS software version 18 .

\section{Results}

Table 1. Frequency of Tongue Lesions in Terms of Location and Gender

\begin{tabular}{|c|c|c|c|c|c|c|c|c|c|}
\hline \multirow{3}{*}{ Subgroups/lesions } & \multirow{2}{*}{\multicolumn{2}{|c|}{ Frequency }} & \multirow{2}{*}{\multicolumn{5}{|c|}{$\begin{array}{l}\text { Site of lesion } \\
\mathrm{N}(\%)\end{array}$}} & \multirow{2}{*}{\multicolumn{2}{|c|}{$\frac{\text { Sex }}{\mathrm{N}(\%)}$}} \\
\hline & & & & & & & & & \\
\hline & Number & Percent & Tip & Dorsal & Lateral & Ventral & Base & $\begin{array}{c}\text { Male } \\
(\%)\end{array}$ & $\begin{array}{c}\text { Female } \\
(\%)\end{array}$ \\
\hline Neoplasms & 67 & $28 \%$ & $4(6 \%)$ & $\begin{array}{c}7 \\
(10.4 \%)\end{array}$ & $\begin{array}{c}37 \\
(55 \%)\end{array}$ & $\begin{array}{c}13 \\
(19.4 \%)\end{array}$ & $6(9 \%)$ & $\begin{array}{c}41 \\
(61 \%)\end{array}$ & $\begin{array}{c}26 \\
(39 \%)\end{array}$ \\
\hline $\begin{array}{l}\text { Squamous cell } \\
\text { carcinoma }\end{array}$ & 59 & $25 \%$ & $3(5 \%)$ & $6(10 \%)$ & $\begin{array}{c}33 \\
(56 \%)\end{array}$ & $12(20 \%)$ & $5(8 \%)$ & $\begin{array}{c}35 \\
(60.7 \%)\end{array}$ & $\begin{array}{c}24 \\
(40 \%)\end{array}$ \\
\hline $\begin{array}{l}\text { Adenosquamous } \\
\text { carcinoma }\end{array}$ & 1 & $0.40 \%$ & & & & & $\begin{array}{c}1 \\
(100 \%)\end{array}$ & & $\begin{array}{c}1 \\
(100 \%)\end{array}$ \\
\hline $\begin{array}{l}\text { Verrucous } \\
\text { carcinoma }\end{array}$ & 1 & $0.40 \%$ & & & $\begin{array}{c}1 \\
(100 \%)\end{array}$ & & & $\begin{array}{c}1 \\
(100 \%)\end{array}$ & \\
\hline Fibrolipoma & 3 & $1.40 \%$ & & $\begin{array}{c}1 \\
(33.3 \%) \\
\end{array}$ & $\begin{array}{c}2 \\
(66.6 \%) \\
\end{array}$ & & & $\begin{array}{c}2 \\
(66.6 \%) \\
\end{array}$ & $\begin{array}{c}1 \\
(33.3 \%) \\
\end{array}$ \\
\hline Neurofibroma & 2 & $0.80 \%$ & & & $1(50 \%)$ & $1(50 \%)$ & & $\begin{array}{c}2 \\
(100 \%) \\
\end{array}$ & \\
\hline Schwannoma & 1 & $0.40 \%$ & $\begin{array}{c}1 \\
(100 \%) \\
\end{array}$ & & & & & $\begin{array}{c}1 \\
(100 \%) \\
\end{array}$ & \\
\hline Reactive lesions & 46 & $19.40 \%$ & $\begin{array}{c}15 \\
(33 \%) \\
\end{array}$ & $13(28 \%)$ & $\begin{array}{c}17 \\
(37 \%) \\
\end{array}$ & $1(2 \%)$ & & $\begin{array}{c}21 \\
(45.5 \%) \\
\end{array}$ & $\begin{array}{c}25 \\
(55.5 \%) \\
\end{array}$ \\
\hline Irritation fibroma & 26 & $11 \%$ & $8(31 \%)$ & $5(19 \%)$ & $\begin{array}{c}12 \\
(46 \%)\end{array}$ & $1(4 \%)$ & & $\begin{array}{c}11 \\
(42 \%)\end{array}$ & $\begin{array}{c}15 \\
(58 \%)\end{array}$ \\
\hline $\begin{array}{l}\text { Pyogenic } \\
\text { granuloma }\end{array}$ & 19 & $7.60 \%$ & $7(37 \%)$ & $8(42 \%)$ & $4(22 \%)$ & & & $\begin{array}{c}10 \\
(52 \%)\end{array}$ & $9(48 \%)$ \\
\hline $\begin{array}{l}\text { Oral focal } \\
\text { mucinosis }\end{array}$ & 1 & $0.40 \%$ & & & $\begin{array}{c}1 \\
(100 \%)\end{array}$ & & & & $1(0.5 \%)$ \\
\hline Hamartomas & 7 & $3 \%$ & $2(29 \%)$ & $3(43 \%)$ & $\begin{array}{c}1 \\
(14.2 \%)\end{array}$ & $\begin{array}{c}1 \\
(14.2 \%)\end{array}$ & & $2(28 \%)$ & $5(72 \%)$ \\
\hline
\end{tabular}


Squamous Cell Carcinoma as the Most Common Lesion of the Tongue in Iranians: a 22-Year Retrospective Study Table 1. Frequency of Tongue Lesions in Terms of Location and Gender (Continued)

\begin{tabular}{|c|c|c|c|c|c|c|c|c|c|}
\hline \multirow{3}{*}{ Subgroups/lesions } & \multirow{2}{*}{\multicolumn{2}{|c|}{ Frequency }} & \multirow{2}{*}{\multicolumn{5}{|c|}{$\begin{array}{l}\text { Site of lesion } \\
\qquad \mathrm{N}(\%)\end{array}$}} & \multirow{2}{*}{\multicolumn{2}{|c|}{$\frac{\text { Sex }}{\mathrm{N}(\%)}$}} \\
\hline & & & & & & & & & \\
\hline & Number & Percent & Tip & Dorsal & Lateral & Ventral & Base & $\begin{array}{c}\text { Male } \\
(\%)\end{array}$ & $\begin{array}{c}\text { Female } \\
(\%)\end{array}$ \\
\hline Hemangioma & 5 & $2.10 \%$ & $2(40 \%)$ & $1(20 \%)$ & $1(20 \%)$ & $1(20 \%)$ & & $1(20 \%)$ & $4(80 \%)$ \\
\hline White- red lesions & 92 & $38.60 \%$ & $\begin{array}{c}16 \\
(17.3 \%)\end{array}$ & $23(25 \%)$ & $\begin{array}{c}47 \\
(50 \%) \\
\end{array}$ & $5(5.4 \%)$ & $\begin{array}{c}2 \\
(2.3 \%) \\
\end{array}$ & $\begin{array}{c}34 \\
(37 \%) \\
\end{array}$ & $\begin{array}{c}58 \\
(63 \%) \\
\end{array}$ \\
\hline Leukoplakia & 31 & $13 \%$ & $\begin{array}{c}3 \\
(9.7 \%) \\
\end{array}$ & $5(16 \%)$ & $\begin{array}{c}19 \\
(61.3 \%) \\
\end{array}$ & $2(6.5 \%)$ & $\begin{array}{c}2 \\
(6.5 \%) \\
\end{array}$ & $\begin{array}{c}14 \\
(46 \%)\end{array}$ & $\begin{array}{c}17 \\
(55 \%) \\
\end{array}$ \\
\hline Benign keratosis & 32 & $13.40 \%$ & $8(25 \%)$ & $\begin{array}{c}4 \\
(12.5 \%)\end{array}$ & $\begin{array}{c}17 \\
(53 \%)\end{array}$ & $3(9.5)$ & & $9(28 \%)$ & $\begin{array}{c}23 \\
(72 \%)\end{array}$ \\
\hline Hairy leukoplakia & 1 & $0.40 \%$ & & & $\begin{array}{c}1 \\
(100 \%)\end{array}$ & & & $\begin{array}{c}1 \\
(100 \%)\end{array}$ & \\
\hline Lichen planus & 18 & $7.50 \%$ & $5(28 \%)$ & $5(28 \%)$ & $8(44 \%)$ & & & $\begin{array}{c}4 \\
(22.3 \%)\end{array}$ & $\begin{array}{c}14 \\
(77.7 \%)\end{array}$ \\
\hline $\begin{array}{l}\text { White spongy } \\
\text { nevus }\end{array}$ & 1 & $0.40 \%$ & & & $\begin{array}{c}1 \\
(100 \%) \\
\end{array}$ & & & $\begin{array}{c}1 \\
(100 \%) \\
\end{array}$ & \\
\hline Candidiasis & 9 & $3.70 \%$ & & $9(100 \%)$ & & & & $5(55 \%)$ & $4(45 \%)$ \\
\hline Ulcers & 18 & $7.60 \%$ & & & $\begin{array}{c}18 \\
(100 \%) \\
\end{array}$ & & & $9(50 \%)$ & $9(50 \%)$ \\
\hline Pemphigoid & 1 & $0.50 \%$ & & & $\begin{array}{c}1 \\
(100 \%)\end{array}$ & & & $\begin{array}{c}1 \\
(100 \%)\end{array}$ & \\
\hline $\begin{array}{l}\text { Non- specific } \\
\text { ulcer }\end{array}$ & 17 & $7.10 \%$ & & & $\begin{array}{c}17 \\
(100 \%)\end{array}$ & & & $8(47 \%)$ & $9(53 \%)$ \\
\hline $\begin{array}{l}\text { Virus-induced } \\
\text { lesions }\end{array}$ & & & & & & & & & \\
\hline $\begin{array}{l}\text { Squamous papil- } \\
\text { loma }\end{array}$ & 8 & $3.30 \%$ & $\begin{array}{c}3 \\
(37.5 \%)\end{array}$ & $\begin{array}{c}1 \\
(12.5 \%)\end{array}$ & $4(50 \%)$ & & & $\begin{array}{c}5 \\
(62.5 \%)\end{array}$ & $\begin{array}{c}3 \\
(37.5 \%)\end{array}$ \\
\hline
\end{tabular}

Hamartomas and virus- induced lesions had the prevalence of $3 \%$ and $3.3 \%$, respectively.

Finally, SCC was found to be the most prevalent (25\%) tongue lesion followed by benign keratosis (frictional keratosis) (13.4\%) and leukoplakia (13\%).

Furthermore, irritation fibroma $(11 \%)$, non- specific ulcers (such as traumatic ulcers) $(7.1 \%)$, and hemangioma $(2.1 \%)$ were the most frequent lesions in their related categories, respectively.Squamous papilloma (3.3\%) was found the only entity among virus-induced lesions (Table 1).

\section{Discussion}

This retrospective study determined the prevalence of tongue lesions in a group of Iranians. In a previous study in Iran, tongue lesions were addressed as a part of oral lesions epidemiology (Mansour et al., 2013). According to this study, the prevalence of tongue lesions in Iranian patients was $3.7 \%$. This rate was reported as $9.2 \%, 12.0 \%, 12.2 \%$, $15.5 \%, 23.7 \%$, and $30.2 \%$ in Libyan, Indian, Brazilian, American, Jordanian, and Malaysian patients, respectively (Shulmanet al., 2004; Byahatti et al., 2010; Koayet al., 2011; Costa et al., 2012; Patil et al., 2013). Other studies were also accomplished in Hungary, Thailand, and Turkey
(Voros-Balog et al., 2003; Jainkittivongand, 2005; Parlak et al., 2006). The difference might be attributable to variations in the ethnicity, geographical characteristics, study design, diagnostic criteria, sample size, distribution of age and sex in the study population, specific habits in some countries or nations, and even differences in socioeconomic level of study population (developed or developing countries) (Costa et al., 2012; Patil et al., 2013).

In our study, men were affected more often (53\%) than women. This finding was in agreement with previous reports (Avcuand, 2003; Voros-Balog et al., 2003; Costa et al., 2012).

With respect to age distribution, tongue lesions were found more commonly (42\%) in patients between 41-60 years of age, which was comparable to that of Costa et al. (2012) and Lin et al. (2001).

In our study population; white-red lesions were the most frequent category, followed by neoplasms, reactive lesions, viral- induced lesions, and hamartomas. In addition, SCC had the highest frequency (25\%) among all tongue lesions. SCC was detected in men more often than women, which in most cases occurred in the lateral border of the tongue. These findings were in accordance with previous reports (Kantola et al., 2001; Costa et al., 
2012; Alaeddiniet al., 2014; Ramddas et al., 2015). On the contrary, lower frequency of tongue SCC has been also reported in Indians, Libyans and Brazilians as $0.3 \%$, $0.9 \%$, and $18 \%$, respectively (Byahattiand, 2010; Costa et al., 2012; Patil et al., 2013).

It is estimated that SCC of the tongue accounts for $25-40 \%$ of all SCC lesions occurring more frequently in developing countries. There is a documented high incidence rate of tongue carcinoma in South and South East Asian parts of Western Europe (France), Eastern Europe, parts of Latin America (Brazil, Uruguay), and pacific regions (Papua New Guinea and Melanesia) (Ramdass et al., 2015).

According to Kantola et al. (2001), 91\% of patients with tongue cancer were older than 40 years, and in $67 \%$ of cases the tumor was located marginally in the tongue. Hernandez-Guerrero et al. (2013) in an epidemiological study showed that the tongue is the predominant anatomic zone for SCC (44.7\%), followed by lips (21.2\%), and gums $(20.5 \%)$ (20). SCC of the tongue, floor of the mouth, and palate was demonstrated to occur in patients younger than 60 years whereas, involvement of the lips and gums were detected in patients older than 60. Saba et al. (2011), in a recent study, showed that $58.6 \%$ of tongue SCCs occurred in males with the peak incidence in 60-70 years.

Despite advances in cancer therapy, 5-year survival rate of oral SCC has not been significantly improved over recent years and remains at about $55 \%$. The mortality rate of oral SCC can be effectively controlled through efforts towards early diagnosis and prevention (Lotfi et al., 2015).

In this report, frequency of neoplastic lesions such as adeno squamous carcinoma, verrucous carcinoma, fibrolipoma, neurofibroma, and schwannoma were close together $(0.4 \%$ to $0.8 \%)$. Except for adeno squamous carcinoma, verrucous carcinoma, neurofibroma, and schwannoma were found only in males. In agreement with us, same results were reported by Costa et al. (2012). Meanwhile, Al-khateeb (2009) showed that only $2 \%$ of benign oral masses were neoplasms with mesenchymal origin. In his study lipoma, schwannoma, and neurofibroma of the tongue were seen in $0.7 \%, 1.4 \%$, and $1.4 \%$ of cases, respectively.

We found that irritation or traumatic fibroma was the most prevalent reactive lesion (11\%) of the tongue, followed by pyogenic granuloma (7.6\%). Similarly, Jafarzadeh et al. (2006) and Al-khateeb et al. (2003) mentioned a lower prevalence $(7 \%)$ for pyogenic granuloma. We also found that irritation fibroma and pyogenic granuloma were more common in females and males, respectively, whereas in two previous studies both entities were most prevalent in females (Jafarzadeh et al., 2006; Costa et al. 2012).

Among hamartomatous lesions of the tongue, hemangioma $(2.1 \%)$, and lymphangioma $(0.8 \%)$ had the highest prevalence in our study. All of the lymphangiomas were located in the dorsum of the tongue; however $40 \%$ of hemangiomas were found in the tongue tip. Previous epidemiologic studies regarding tongue hemangioma reported prevalence at $0.3 \%, 0.9 \%, 6 \%$, and $12 \%$ in Indian, Libyan, Brazilian, and Jordanian population (Al-Khateeb 2009; Byahattiand, 2010; Costa et al., 2012; Patil et al.
2013). Lymphangioma of the tongue was reported in $0.3 \%$, $2 \%$, and $0.7 \%$ of patients by ByahattiandIngafou (2010), Costa et al. (2012), and Al-khateeb (2009) as well.

Benign keratosis (frictional keratosis) (13.4\%), leukoplakia (13\%), lichen planus (7.5\%), and candidiasis (9\%) were the most prevalent white-red lesions of the tongue. The prevalence of frictional keratosis in the present study was higher than those of Slovian (2.2\%) (Kovac-Kovacicand Skaleric, 2000) and Spanish (7.5\%) population (Garcia-Pola et al., 2002). This entity affected females more commonly (72\%) than men with most cases occurring in the lateral borders of the tongue.We noticed leukoplakia more frequently in females in accordance with Cebeci et al. (2009). Prevalence of this phenomenon was $0.3 \%$ and $3 \%$ in Libyans and Indians, respectively (ByahattiandIngafou, 2010; Patil et al., 2013). Lichen planus was observed in $7.5 \%$ of our patients and it was most commonly seen in women. The prevalence measured at $1 \%, 2.2 \%, 2.3 \%$, and 3.2\% in several studies (KovacKovacicand, 2000; Garcia-Pola al., 2002; Byahattiand, 2010; Patil et al., 2013). A retrospective study on oral lichen planus in Brazilians showed the tongue being affected in $36 \%$ of all cases (Sousa et al., 2002). Costa et al. (2012) reported the prevalence of the tongue lichen planus to be $1 \%$, and did not found any malignant transformation or lichenoid dysplasia; however Carbone et al. (2009) showed 15 patients with tongue lichen planus evolving into SCC. In our study, white spongy nevus was only seen in males. All candidiasis cases were located in the dorsum of the tongue.All of non- specific ulcerations such as traumatic ulcers were seen in the tongue margins. Fifty percent of squamous papilloma was located in the lateral border of the tongue with men being more affected.

In conclusion, squamous cell carcinoma was found to be the most common tongue lesion with a male predilection in an Iranian population.

\section{Acknowledgements}

The authors are greatly thankful to the staff of Oral Pathology Department for their utmost cooperation. The authors declare no source of funding.

\section{References}

Alaeddini M, Barghammadi R, Eshghyar N, et al (2014). An analysis of biopsy-proven tongue lesions among 8,105 dental outpatients. J Contemp Dent Pract, 15, 1-7.

Al-Khateeb T, Ababneh K (2003).Oral pyogenic granuloma in Jordanians: a retrospective analysis of 108 cases. J Oral Maxillofac Surg, 61, 1285-8.

Al-Khateeb TH (2009). Benign oral masses in a Northern Jordanian population-a retrospective study. Open Dent $J$, 3, 147-53.

Avcu N, Kanli A (2010). The prevalence of tongue lesions in 5150 Turkish dental outpatients. Oral Dis, 9, 188-95

Byahatti SM, Ingafou MSH (2010). The prevalence of tongue lesions in Libyan adult patients. J ClinExp Dent, 2, 163-8.

Carbone M, Arduino PG, Carrozzo M, et al (2009). Course of oral lichen planus: a retrospective study of 808 northern Italian patients. Oral Dis, 15, 235-43.

Cebeci AR, Gülşahi A, Kamburoglu K, et al (2009). Prevalence 

and distribution of oral mucosal lesions in an adult Turkish population. Med Oral Patol Oral Cir Bucal, 14, E272-7.

Costa FW, Osterne RL, Mota MR, et al (2012). Tongue lesions. J Craniofac Surg, 23, 548-51.

Garcia-Pola Vallejo MJ, Martinez Diaz-Canel AI, Garcia Martin JM, et al (2002). Risk factors for oral soft tissue lesions in an adult Spanish population. Community Dent Oral Epidemiol, 30, $277-85$.

Hernandez-Guerrero JC, Jacinto-Aleman LF, Jimenez-Farfan MD, et al (2013). Prevalence trends of oral squamous cell carcinoma. Mexico City's General Hospital experience. Med Oral Patol Oral Cir Bucal, 18, 306-11.

Jafarzadeh H, Sanatkhani M, MohtashamN (2006). Oral pyogenic granuloma: a review. J Oral Sci, 48, 167-75.

Jainkittivong A, Langlais RP (2005). Geographic tongue: clinical characteristics of 188 cases. J Contemp Dent Pract, 6, 123-35.

Kantola S, Jokinen K, Hyrynkangas K, et al (2001). Detection of tongue cancer in primary care. Br J Gen Pract, 51, 106-11.

Koay CL, Lim JA, SiarCH (2011).The prevalence of tongue lesions in Malaysian dental outpatients from the Klang Valley area. Oral Dis, 17, 210-6.

Kovac-Kovacic M, Skaleric U (2000). The prevalence of oral mucosal lesions in a population in Ljubljana, Slovenia. $J$ Oral Pathol Med, 29, 331-5.

Lin HC, Corbet EF, Lo EC (2001). Oral mucosal lesions in adult Chinese. J Dent Res, 80, 1486-90.

Lotfi A, Shahidi N, Bayazian G, et al (2015). Serum level of Interleukin-6 in Patients with oral tongue squamous cell carcinoma. Iran J Otorhinolaryngol, 27, 207-11.

Mansour Ghanaei F, Joukar F, Rabiei M, et al (2013). Prevalence of oral mucosal lesions in an adult Iranian population.Iran Red Crescent Med J, 15, 600-4.

Parlak AH, Koybasi S, Yavuz T, et al (2006). Prevalence of oral lesions in 13- to 16-year-old students in Duzce, Turkey. Oral Dis, 12, 553-8.

Patil S, Kaswan S, Rahman F, et al (2013). Prevalence of tongue lesions in the Indian population. J Clin Exp Dent, 5, 128-32.

Ramdass MJ, Harracksingh A, Maharaj K, et al (2015). Incidence of tongue carcinoma in Trinidad and Tobago, West Indies. Oncol Lett, 9, 1417-9.

Saba NF, Goodman M, Ward K, et al (2011). Gender and ethnic disparities in incidence and survival of squamous cell carcinoma of the oral tongue, base of tongue, and tonsils: a surveillance, epidemiology and end results program-based analysis. Oncol, 81, 12-20.

Shulman JD, Beach MM, Rivera-Hidalgo F (2004). The prevalence of oral mucosal lesions in U.S. adults: data from the Third National Health and Nutrition Examination Survey, 1988-1994. J Am Dent Assoc, 135, 1279-86.

Sousa FB, Etges A, Correa L, Mesquita RA, de Araujo NS (2002). Pediatric oral lesions: a 15-year review from São Paulo, Brazil. JClinPediatr Dent, 26, 413-8.

Voros-Balog T, Vincze N, BanoczyJ (2003). Prevalence of tongue lesions in Hungarian children. Oral Dis, 9, 84-7. 